DOI: https://doi.org/10.47405/mjssh.v5i12.593

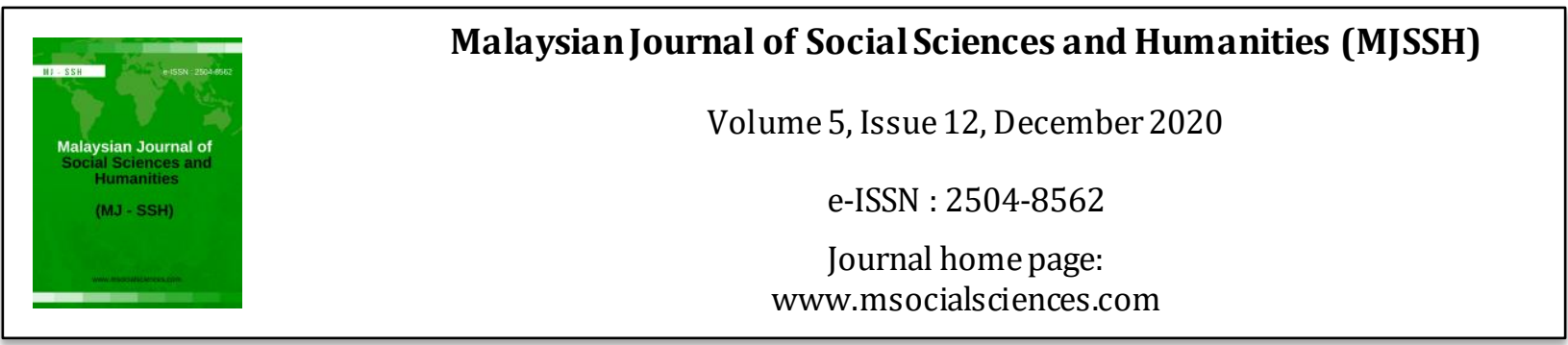

\title{
Pengamalan Nilai Agama dalam Mengatasi Kemurungan Semasa Pandemik COVID-19
}

\author{
Abdul Rashid Abdul Aziz', Amin Al Haadi Shafie1, Zuraina Ali2 , Noor Dahiah Sulhana Dzainal1 \\ ${ }^{1}$ Fakulti Kepimpinan dan Pengurusan, Universiti Sains Islam Malaysia (USIM) \\ ${ }^{2}$ Pusat Bahasa Moden, Universiti Malaysia Pahang (UMP) \\ Correspondence: Abdul Rashid Abdul Aziz (rashid@usim.edu.my)
}

\begin{abstract}
Abstrak
Wabak Coronavirus Disease 2019 (COVID-19) yang telah diisytiharkan sebagai pandemik oleh Pertubuhan Kesihatan Sedunia atau World Health Organization (WHO) telah menyebabkan ramai rakyat Malaysia mengalami masalah kemurungan. Kemurungan boleh mengganggu aspek psikologi dan kesejahteraan kendiri yang merupakan elemen penting dalam menentukan kefungsian diri manusia dan mempengaruhi sistem kesihatan dalam menghadapi penularan wabak ini. Justeru, penulisan ini bertujuan melihat cabaran kemurungan semasa pandemik COVID-19 yang menumpukan kepada aspek spiritualiti (kerohanian) bagi mencari solusi kepada kepulihan dan perubahan dalam masalah kemurungan. Kajian perpustakaan melalui kaedah analisis kandungan telah digunakan dalam kajian ini bagi merungkai cabaran dan solusi terhadap masalah kemurungan. Teori Psiko Spiritual al-Ghazali telah dirujuk bagi membantu pemahaman dalam permasalahan yang dihadapi ini. Kajian mendapati bahawa COVID-19 telah membawa kepada pelbagai implikasi yang mengundang kemurungan. Selain itu, melalui pendekatan terapi psikospiritual dengan kaedah solat, zikir, doa, amalan filantropi dan rasa redha dilihat sebagai salah satu platform alternatif yang boleh digunakan dalam menangani masalah kemurungan. Oleh itu, melalui pemahaman terhadap implikasi kemurungan, langkah pencegahan yang terpilih mengikut pendekatan yang bersesuaian dapat dilaksanakan agar masalah kemurungan dapat dirawat dan seterusnya menjamin kesejahteraan individu yang terkesan dengan wabak COVID-19.
\end{abstract}

Kata kunci: kemurungan, tekanan psikologi, psiko spiritual, COVID-19

\section{Practice of Religious Values in Overcoming Depression during COVID-19 Pandemic}

\begin{abstract}
Coronavirus Disease Disease 2019 (COVID-19) which has been declared a pandemic by the World Health Organization (WHO) has caused many Malaysians to suffer from depression. Depression can interfere with the psychological aspects and self well-being which are important elements in determining human functioning and influencing the health system in dealing with the spread of this pandemic. Thus, this study aims to look at the challenges in depression sufferer during COVID-19 pandemic focusing in spirituality aspect to find solutions for recovery. Library research through content analysis method has been used in this study to unravel the challenges and solutions to depression. Al-Ghazali's Psycho-spiritual Theory has been referred to to aid understanding in this problem. Study has found that COVID-19 has led to a variety of implications that invite depression. In addition, through the approach of psychospiritual therapy with the methods of solat, dhikr, prayer, philanthropic practice and 'redha' is seen as one of the alternative platforms that can be used in
\end{abstract}


dealing with depression. Therefore, through an understanding of the implications of depression, selected preventive measures according to the appropriate approach can be implemented so that depression can be treated and ensure the well-being of individuals affected by the COVID-19 pandemic is optimized.

Keywords: depression, psychological stress, psychospiritual, COVID-19

\section{Pengenalan}

Mutakhir ini, masyarakat Malaysia khususnya dalam kalangan umat Islam semakin kerap menghadapi ketidakseimbangan emosi, psikologi, dan kognitif sehingga menimbulkan masalah kecelaruan jiwa. Rentetan itu, teori barat seperti psikoanalisis, humanistik, terapi tingkah laku, gestalt, dan banyak lagi dilihat mempunyai kelemahan tersendiri apabila mengabaikan aspek dalaman iaitu roh dan unsur kerohanian. Oleh yang demikian, menjadi satu keperluan kepada bidang psikoterapi untuk menyuntik elemen agama dan kerohanian bagi meningkatkan aspek kesihatan dan kesejahteraan diri (Sharifah \& Che Zarrina, 2015). Ini bertepatan dengan konsep pemahaman manusia menurut agama Islam yang banyak dipengaruhi oleh unsur dalaman diri seperti Roh, Nafs, Aql dan Qalb (Ibnu Qayyim, 2017). Sheikh Abu Talib Al-Makki dalam kitabnya Qut al-Qulub (Abdul Rachman, 2015), Imam al-Ghazali dalam kitab Ihya' Ulumuddin (Zaid, 2013) dan Tazkiah an-Nafs karya Ibnu Qayyim al-Jauziyah (Abu umar, 2017) telah mengupas elemen diri manusia dengan lebih mendalam dari sudut tasawuf yang membawa kepada pemahaman tingkah laku manusia dalam konteks sekarang. Hal ini penting kerana pendekatan psikoterapi Islam yang merujuk kepada perbahasan ulama terdahulu mampu membantu pesakit dalam mengurangkan tekanan atau stres yang dialami (Che Zarrina \& Norhafizah, 2019). Malah, dalam perspektif perubatan, beberapa kajian yang dijalankan mendapati nilai keagamaan dapat meningkatkan kesejahteraan dan kepatuhan pesakit terhadap rawatan yang diterima (Mitchell \& Romans, 2003; Marcotte et al., 2003).

Di dalam Islam, elemen batiniah yang tercela membawa kepada gangguan kejiwaan yang ditonjolkan dalam bentuk marah, sedih, cemas, pilu, resah, gelisah hati, jiwa tidak tenteram dan berasa tiada daya untuk mengatasi persoalan hidup. Gejala ini bukan sahaja memberi kesan kepada jiwa dan psikologi, malah turut memberi impak buruk kepada kesihatan jasmani, mental dan tubuh badan (Sharifah Basirah \& Che Zarrina, 2015). Oleh itu, aspek kesihatan mental memerlukan rakyat mempunyai kemahiran daya tahan dan jati diri yang kukuh bagi melahirkan insan mandiri yang seimbang dari aspek dalaman dan luaran. Walau bagaimanapun, disiplin ilmu agama dalam memahami dan merawat masalah jiwa dan kemurungan masih terhad dijalankan secara empirikal disebabkan percambahan teori barat yang banyak meninggalkan hal agama dalam membincangkan isu berhubung kesihatan mental (Mohd Nasir, 2016). Malah hanya 29 peratus ahli terapi yang percaya bahawa elemen agama adalah penting dalam membantu kepulihan dan rawatan (Sapora, 2009)

Di samping itu, pengiktirafan terhadap keperluan agama dalam proses membantu individu yang mempunyai masalah kesihatan mental juga semakin mendapat perhatian di barat (Skinner, 2018). Keperluan elemen agama sebagai intervensi juga telah diperakui oleh badan profesional seperti American Psychological Association (APA) dan America Counseling Association yang mengiktiraf dan mengakui bahawa agama merupakan satu elemen yang memberikan sumbangan kepada perkembangan dan kefungsian manusia. APA telah meletakkan religiositi pada bahagian ke-36 sebagai salah satu bahagian daripada beberapa bahagian psikologi yang diiktiraf (APA, 2011). Berdasarkan sokongan tersebut, elemen agama ini juga turut menjadi keperluan untuk dipraktikkan dalam kehidupan generasi belia di Malaysia.

Kemurungan merupakan isu kesihatan global yang menjadi polemik masa kini dengan angka lebih dari 300 juta penderita di seluruh dunia dan angka tersebut terus meningkat (Toghyani et al., 2018; World Health Organization, 2019). Beban masalah mental ini terus menjadi liabiliti terbesar yang memberi impak kepada aspek kesihatan, sosial, dan ekonomi (Jenkins et al., 2011). Pertubuhan Kesihatan Sedunia (WHO) menganggarkan seorang daripada empat orang remaja dan kanak-kanak mengalami 
masalah mental. Berdasarkan Tinjauan Kebangsaan Kesihatan dan Morbiditi (National Health and Morbidity Survey, NHMS) 2019, hampir setengah juta rakyat (2.3 peratus) di negara ini dalam kalangan dewasa didapati mengalami simptom tekanan atau depresi. Daripada jumlah ini, majoriti individu yang terkesan adalah individu dalam golongan B40 (2.7 peratus), diikuti oleh golongan M40 (1.7 peratus) dan T20 (0.5 peratus). Dalam masa yang sama, NHMS 2019 juga mendapati seramai 424,000 orang kanak-kanak (7.9\%) mengalami masalah kesihatan mental. Separuh daripada masalah gangguan mental ini bermula seawal usia 14 tahun dan tiga per empat daripadanya berlaku pada pertengahan usia 20an (Berita Harian, 2020). Data laporan tahunan Kementerian Kesihatan (KKM) pada 2018 merekodkan 465 kes cubaan bunuh diri antara Januari sehingga Jun 2020.

Penularan wabak COVID-19 sememangnya telah memberikan impak negatif dalam pelbagai aspek terhadap seluruh masyarakat dunia termasuklah dalam isu kesihatan mental manusia. Aspek kesihatan mental ini sering kali diabaikan dan dipandang enteng oleh masyarakat kita kerana ia biasanya tidak terzahir secara fizikal. Namun, apabila masalah ini berlaku secara terus menerus dalam tempoh masa yang lama, ia semestinya akan memberikan kesan terhadap kesihatan fizikal. Wabak COVID-19 pula dilihat sebagai mimpi ngeri yang menakutkan kerana telah mengubah pola kehidupan manusia termasuklah cara kebanyakan individu bekerja, bersosial, belajar, mengakses kepada penjagaan kesihatan, membeli-belah dan melalui aktiviti kehidupan. Sehingga bulan November 2020, wabak Covid-19 telah mencatat lebih 60 juta kes dengan angka kematian lebih dari 1.4 juta orang serta melibatkan keseluruhan 220 buah negara yang terjejas di seluruh dunia (Statistik WHO, 2020). Manakala di Malaysia, menurut statistik Kementerian Kesihatan Malaysia (KKM) sehingga bulan November 2020 pula mencatatkan jumlah kes positif COVID-19 sebanyak 60,000 orang dengan 350 angka kematian.

Sehubungan dengan fenomena COVID-19 ini, ramai yang mula berasa cemas, risau, tertekan, bimbang dan takut dengan kemunculan wabak ini. Oleh itu, setiap individu berpotensi mengalami isu melibatkan kesihatan mental seperti kemurungan. Selain golongan yang berisiko seperti pesakit COVID-19, ahli keluarga pesakit serta petugas di barisan hadapan (frontliner), pelaksanaan Perintah Kawalan Pergerakan (PKP) yang dijalankan juga menyebabkan ramai individu yang kehilangan pekerjaan, batasan pergerakan dan simptom cabin fever atau 'demam terperuk' semasa norma baharu juga membawa kepada gejala kesihatan mental seperti kemurungan. Justeru, kajian ini adalah bertujuan untuk melihat cabaran kemurungan semasa pandemik COVID-19 yang menumpukan kepada aspek spiritualiti (kerohanian) bagi mencari solusi kepada kepulihan dan perubahan dalam masalah kemurungan.

\section{Sorotan Literatur}

Dasar Kesihatan Mental Negara (2013) menyasarkan beberapa objektif dalam melahirkan masyarakat yang seimbang dan sihat dari segi psikologi yang mana antara objektifnya adalah menyediakan suatu asas, strategi perancangan dan pelaksanaan program bagi tujuan untuk memperbaiki aspek kesihatan mental dan kesejahteraan seluruh rakyat. Selain itu, antara objektifnya adalah untuk memperbaiki perkhidmatan kesihatan mental bagi populasi yang menghadapi risiko, memperbaiki perkhidmatan psikiatri, dan berusaha membekalkan penjagaan kesihatan mental kepada individu, keluarga, masyarakat dan badan-badan yang berkaitan melalui kempen dan program dijalankan. Malah Dasar Kesihatan Mental juga menekankan aspek penyelidikan di mana dasar ini sangat mengalu-alukan penyelidikan dan program pembangunan ke arah meningkatkan aspek kesihatan mental rakyat yang lebih baik (Kementerian Kesihatan Malaysia, 2013).

Menurut Nurrussakinah (2014), peranan psikologi Islam adalah berbeza dengan psikologi barat. Psikologi barat hanya menerangkan, mengawal dan membuat ramalan terhadap tingkah laku manusia, sebaliknya psikologi Islam menerangkan, mengawal, membuat ramalan terhadap tingkah laku dan mengarahkan manusia untuk mendapat redha Allah. Jadi misi utama psikologi Islam adalah untuk menyelamatkan manusia dan mendorong manusia memenuhi kecenderungan alaminya dan fitrahnya untuk kembali kepada Allah. Hal ini kerana, persepsi dan kefahaman yang salah memburukkan 
masalah pesakit jiwa, maka untuk mengelakkan kekeliruan dari segi kewujudan dan peranan manusia itu sendiri, persepsi dan pemikiran yang benar tentang Islam perlu diterapkan (Siti Zalikhah, 2002).

Sharifah (2017) telah menjalankan kajian bagi membangunkan Model Psikoterapi al-Makki (MPM) dan modul intervensi untuk penghidap masalah kebimbangan (anxiety disorder). Model MPM ini dibangunkan berlandaskan ilmu tasawuf, berasaskan konsep sembilan maqamat sebagaimana yang dikemukakan oleh seorang tokoh Sufi terkenal, Shaykh Abu Talib al- Makki dalam karyanya Qut alQulub. Dapatan kajian menunjukkan model dan modul yang dibangunkan ini telah memberi kesan yang positif kepada subjek kajian dan mampu berperanan sebagai panduan bagi memupuk peluang, semangat, dorongan dan galakan dalam usaha merawat masalah al-halu' yang dihidapi. Dalam kajian lain yang dijalankan oleh Siti Jamiaah (2017) pula mendapati nilai asas keagamaan dari aspek kekuatan akidah berupaya memberi kesan positif terhadap konsep kendiri dan menangani masalah kebimbangan dan kemurungan dalam kalangan banduan wanita. Antara aspek yang dikaji ialah berkaitan program keagamaan yang dilaksanakan di penjara yang dikenali sebagai Program Pembangunan Sahsiah (PPS) dan bentuk-bentuk sokongan sosial yang disediakan oleh pihak Jabatan Penjara Malaysia (JPM) kepada banduan.

Manakala Rahim et al. (2019) juga mendapati bahawa Islam memiliki tatacara al-tafakkur atau kontemplasi tersendiri yang realistik dalam mendepani isu kesihatan mental. Kaedah al-tafakkur menurut Sunnah dilihat mempunyai fungsi holistik dan seimbang berbanding metod meditasi konvensional dalam agama lain seperti Transcendental Meditation, Yoga dan lain-lain metod rawatan psikoterapi bukan Islam. Kajian ini juga mendapati metod al-tafakkur menurut sunnah adalah lebih berkesan berbanding meditasi komplimentari bukan Islam dalam berperanan sebagai model psikoterapi alternatif khususnya bagi individu Muslim yang menghadapi isu kesihatan mental. Selain itu, Norhafizah dan Zarrina (2019) telah mengkaji pendekatan psikoterapi Islam dalam mengurus tekanan yang dialami oleh pesakit kronik. Hasil kajian merumuskan bahawa pendekatan psikoterapi Islam merujuk kepada perbahasan ulama terdahulu mampu membantu pesakit dalam mengurangkan tekanan atau stres yang dialami. Namun, usaha untuk mendapat kepulihan dan mencapai kepada tahap kestabilan emosi dan ketenangan jiwa juga memerlukan kepada konsistensi dalam amalan dilakukan serta penghayatan bagi amalan tersebut.

Di luar negara, dalam kajian Lucette (2016) mendapati bahawa keadaan kronik sesuatu penyakit adalah berkait secara konsisten dengan simptom kemurungan. Kajian ini juga mendapati lebih banyak praktis nilai keagamaan dan kerohanian dalam diri subjek menyebabkan simptom kemurungan kurang ketara dan mudah dipulihkan dalam diri subjek kajian. Tambahan itu, Walaa dan Adarsh (2013) pula mendapati bahawa nilai-nilai dan kepercayaan Islam telah dilihat mampu membantu dalam merawat orang-orang Islam yang mengalami masalah kesihatan mental. Melalui penggabungan dan penambahan aspek nilai mengikut perspektif Islam dalam teknik psikoterapi, keperluan pesakit-pesakit Islam seperti dalam penyalahgunaan dadah dan masalah kesihatan mental yang lain telah dapat dipenuhi dan juga memberikan impak yang besar dalam perubahan diri mereka. Hal ini termasuklah memberi tumpuan kepada pengubahsuaian teknik psiko terapeutik seperti 'Motivation-enhanced Psychotherapy' dan lainlain sebagai penstrukturan semula kognitif pesakit dengan suntikan elemen Islam.

\section{Pendekatan Teori}

\section{Teori Kaunseling Psiko-Spiritual Al-Ghazali}

Kemerosotan kerohanian merupakan suatu isu dan cabaran kaunseling di Malaysia (Mohd Tajudin \& Rohany, 2014). Bagi mereka yang beragama Islam, kemerosotan kerohanian ini dibimbangi akan membawa kepada kemiskinan psikologi dan kemiskinan akidah. Kemiskinan psikologi dalam konteks ini merujuk kepada individu yang berhadapan dengan masalah psikologi seperti kemurungan, lemah semangat, mempunyai pandangan yang negatif dan kurang bermotivasi. Manakala kemiskinan akidah dalam konteks ini bermaksud individu yang mempunyai kurang penghayatan dan pengamalan keagamaan (Nor Ezdianie \& Mohd Tajudin, 2017). Teori Kaunseling Psiko-spiritual al-Ghazali 
merupakan suatu pendekatan yang menggabungkan elemen spiritualiti dan keagamaan yang bersumberkan al-Quran dan al-Hadis (Yatimah \& Mohd Tajudin, 2011).

Imam Al-Ghazali (2000) telah membezakan antara elemen roh dan jasad. Roh adalah elemen nyawa yang menghidupkan manusia tanpa perlu bergantung kepada elemen lain, manakala jasad adalah elemen yang bergantung kepada roh. Teori Kaunseling al-Ghazali menjadikan falsafah al-Ghazali tentang unsur qalb, ruh, nafs dan 'aql sebagai teras dalam pembinaan teori ini. Teori Kaunseling alGhazali menghuraikan sifat-sifat manusia terdiri daripada empat unsur iaitu qalb atau hati, ruh atau roh, nafs atau jiwa, dan 'aql atau akal (Yatimah dan Mohd Tajudin, 2008, 2011). Keempat-empat unsur ini berinteraksi secara dinamik. Unsur qalb iaitu hati, ruh iaitu spiritual dan nafs iaitu jiwa adalah unsur yang mempengaruhi sifat dalaman manusia manakala 'aql iaitu minda adalah unsur yang mempengaruhi sifat luaran manusia. Namun begitu unsur yang paling penting yang mempengaruhi tingkah laku manusia adalah qalb (Abdul Hamid, 1988).

Hati dalam pengertian yang abstrak lebih memberi kesan kepada diri manusia dan diumpamakan sebagai raja. Ia mempunyai pembantu ataupun 'tentera' yang 'bertugas' melayani suruhannya iaitu anggota tubuh seperti tangan, kaki, mata, telinga, lidah dan sebagainya. Secara naluri, seluruh anggota manusia patuh kepada hati. Al-Ghazali membahagikan 'tentera hati' kepada zahir dan batin yang bekerjasama memacu diri individu ke arah mendekatkan diri kepada Allah SWT. Penekanan terhadap hati dalam kehidupan manusia dilanjutkan pula dalam huraiannya pada tahap kualiti hidup manusia. Kualiti manusia di hadapan Allah SWT mahupun pada pandangan manusia ditentukan oleh aspek dalaman yang diterajui oleh hati. Hati menjadi daya dorong tingkah laku dan rupa luarannya (Noor Shakirah, 2008).

Berasaskan teori kaunseling al-Ghazali, Yatimah dan Mohd Tajudin (2011) merumuskan lima langkah yang dapat membantu individu mencari penyelesaian dalam masalah berkaitan aspek kesihatan emosi dan mental. Langkah pertama adalah dengan pengenalan dan pembinaan hubungan. Langkah ini adalah melibatkan elemen berdoa, berjanji dan bertawakal, berbincang tentang konsep-konsep Islam (matlamat hidup, kewajipan, hukum perlakuan, halal haram, musibah, sabar dan syukur, sifat-sifat Allah dan Sunnah rasul mengikut keperluan kes. Langkah ke dua adalah dengan mengenal diri dan bina matlamat hidup. Langkah ini pula melibatkan penerokaan kriteria diri klien yang membawa kepada masalah berdasarkan pemerhatian, percakapan dan soalan andaian, membimbing klien membuat muhasabah diri dalam melaksanakan syariat, klien menyedari kelalaian dan kekurangan yang ada pada dirinya. Langkah ketiga merupakan mengenal pasti punca dan jenis masalah. Dalam langkah ini, ia melibatkan gabungan langkah satu dan dua yang menjadi asas meneroka punca dan jenis masalah, kaunselor dan klien mencapai kefahaman yang sama mengenai diri dan permasalahan klien, rumusan masalah melibatkan kefahaman Islam dan penghayatan atau amalan syariat klien. Langkah keempat adalah dengan memberi ubat yang sesuai dengan jenis penyakit. Langkah ini melibatkan klien akan memperbaiki diri melalui mempelajari ilmu Islam seperti meningkatkan amalan, bertaubat, berzikir, berdoa, menjaga pergaulan, menjauhi maksiat, menjaga makan minum, menjaga pandangan, menjaga pertuturan, menjaga daripada penyakit hati seperti sombong, riyak, ujub dan takbur. Langkah kelima iaitu langkah yang terakhir adalah penilaian. Langkah terakhir ini adalah melibatkan penilaian kaunselor terhadap klien berdasarkan perubahan klien melalui air muka, gerak-geri dan pertuturan dari segi peningkatan aqidah, memahami diri, reda dengan musibah, keyakinan diri yang tinggi, melaksanakan tuntutan agama, taqwa dan tawakal.

\section{Metod Kajian}

Kajian ini menggunakan kaedah kajian kualitatif menerusi kajian perpustakaan untuk mencari maklumat sekunder yang berkaitan dengan pengamalan nilai agama dalam isu kesihatan mental dikala wabak COVID-19 yang semakin menular ini. Maklumat-maklumat yang diperoleh adalah daripada pelbagai sumber seperti buku, jurnal, dan artikel akhbar serta majalah. Maklumat ini dikumpulkan dan disaring serta dianalisis menggunakan teknik analisis kandungan. Analisis kandungan terhasil apabila pengkaji mempunyai matlamat untuk menjalankan kajian literatur pengkaji. Justeru, daripada analisis 
yang dijalankan, pengkaji dapat mengenal pasti impak COVID-19 terhadap kemurungan serta pengamalan nilai agama yang boleh dipraktikkan.

\section{Hasil Kajian dan Perbincangan Kajian}

Kesihatan mental merujuk kepada kesejahteraan daripada sudut psikologi, sosial dan minda. Menurut Pertubuhan Kesihatan Sedunia (WHO), kesihatan mental adalah kebolehupayaan seseorang dalam mengenal pasti potensi, kemahiran untuk mengatasi stres, produktiviti dan keupayaan dalam memberikan sumbangan kepada masyarakat. Depresi, gelisah dan stres adalah antara beberapa penyakit yang kebiasaannya dikaitkan dengan kecelaruan minda yang boleh memberi kesan langsung kepada perkembangan berfikir, perasaan, tingkah laku dan juga boleh mengganggu aktiviti seharian seseorang.

\section{Implikasi COVID-19 Membawa Kepada Kemurungan}

Pertubuhan Bangsa-bangsa Bersatu (PBB) menyifatkan penularan COVID-19 berisiko mencetuskan krisis kesihatan mental global sekali gus tindakan segera perlu diambil bagi menangani penderitaan psikologi yang ditimbulkan oleh pandemik ini. Ketika perlindungan dan aspek kesihatan fizikal menjadi perhatian utama, PBB memberi amaran bahawa wabak COVID-19 juga boleh menyebabkan tekanan mental yang membabitkan sejumlah besar populasi penduduk dunia (Berita harian, 2020). Situasi semasa seperti ketakutan, ketidakpastian dan kemelut ekonomi boleh membawa kepada tekanan psikologi (Devora, 2020). Sekiranya jumlah individu yang dijangkiti semakin ramai, maka risiko untuk masyarakat mengalami tekanan perasaan juga akan meningkat termasuk dalam kalangan pesakit COVID-19 itu sendiri. Justeru, keadaan itu seterusnya akan memberi kesan terhadap ahli keluarga dan individu terdekat serta tidak terkecuali petugas kesihatan yang merawat pesakit berikutan bebanan kerja yang semakin bertambah (Devora, 2020).

\section{Persediaan Diri Pesakit\& Petugas Barisan Hadapan (Frontliner)}

Individu yang telah disahkan positif COVID-19, mempunyai kebimbangan terhadap penyakit, ketidaktentuan tentang penyembuhan serta perasaan bersalah kerana menjadi punca penyakit ini tersebar kepada individu lain. Dalam pada masa yang sama, mereka perlu berada di hospital untuk jangka masa yang lama di sepanjang tempoh kuarantin yang dijalankan dan terpaksa diasingkan serta berjauhan daripada keluarga. Sekiranya, perasaan dan emosi ini tidak diurus dengan baik, kemungkinan besar untuk individu mendapat kemurungan adalah sangat tinggi (Firdaus, 2020).

Di samping itu, petugas kesihatan seperti pegawai perubatan, jururawat dan petugas barisan hadapan (frontliner) yang terdedah kepada pesakit COVID-19 dihantui kebimbangan tentang risiko mendapat penyakit, ditambah dengan masa bekerja yang panjang sehingga menyebabkan kepenatan serta tidak dapat mengambil cuti disebabkan bebanan kerja yang kian bertambah (Shawaludin, 2020). Pengalaman melihat mereka yang dijangkiti wabak serta pengendalian kes yang teruk juga mendedahkan kepada tekanan dan trauma (Firdaus, 2020). Kebimbangan akan dirasai jika jumlah pesakit terus meningkat, sedangkan petugas kesihatan mengalami keletihan emosi, mental dan fizikal berikutan tekanan kerja berlebihan dan berpanjangan. Kesemua rantaian ini memberi implikasi besar kepada pelbagai aspek yang melibatkan kesihatan mental (Muhammad Muhsin, 2020).

\section{Isu kerjaya dan kewangan}

Berdasarkan laporan terkini Jabatan Perangkaan Malaysia dalam Perangkaan Tenaga Buruh Malaysia (2020), kadar pengangguran pada Mac 2020 melonjak kepada 3.9 peratus. Kadar pengangguran ini meningkat berbanding 3.3 peratus pada bulan sebelumnya dan ia merupakan kadar tertinggi semenjak Jun 2010 (3.6 peratus). Dalam perangkaan tersebut, didapati jumlah penganggur telah meningkat kepada 610.5 ribu orang (17.1 peratus) berbanding 521.3 ribu orang pada bulan yang sama tahun 2019 . Kadar pengangguran yang tinggi pada Mac 2020 ini adalah dipengaruhi oleh impak negatif Perintah 
Kawalan Pergerakan (PKP) ke atas pasaran buruh. Statistik ini dianggarkan terus bertambah berikutan penularan wabak COVID-19 yang dilihat masih belum reda.

Tempoh masa pandemik yang tidak menentu serta jangka masa arahan PKP menjadi punca keresahan rakyat termasuklah golongan majikan dan pekerja. Ketika ini, setiap individu mungkin berhadapan tekanan berbeza sebagai contoh majikan bimbang mengenai perniagaan dan sumber kewangan. Manakala, pekerja pula berasa bimbang memikirkan kelangsungan kerjaya mereka. Dalam masa yang sama, terdapat majikan yang menawarkan pekerja cuti tanpa gaji serta terpaksa memecat pekerja ekoran wabak ini. Ini bermaksud, bukan sahaja gejala penyakit tetapi faktor ekonomi turut memberi kesan kepada masyarakat dan individu secara psikologi sehingga menimbulkan gangguan dalam kehidupan seharian (Firdaus, 2020). Aspek kewangan sering kali menjadi punca kritikal yang boleh membawa kepada tekanan hidup dan masalah mental sekiranya gagal ditangani lebih-lebih lagi bagi mereka yang mempunyai tanggungan serta beban hutang yang banyak. Rentetan dari kehilangan pekerjaan semasa pandemik COVID-19 ini, terdapat individu yang membunuh diri dengan menggantung diri (Fadh, 2020; Hafidzul, 2020).

\section{Norma Baharu Pembelajaran dalam Kalangan Pelajar}

Kesihatan mental adalah satu cabaran besar yang terpaksa dialami oleh semua pihak sepanjang tempoh pandemik COVID-19. Ancaman yang lahir akibat daripada virus korona ini bukan sahaja memberi kesan kepada fizikal, tetapi juga mental masyarakat secara amnya dan pelajar yang tinggal di kampus secara khususnya. Tempoh Perintah Kawalan Pergerakan (PKP) yang tidak pasti durasinya menimbulkan pelbagai kekeliruan dan kerisauan dan mengganggu kelangsungan aktiviti-aktiviti seperti kelas pengajian, latihan industri, tempoh graduasi serta bayaran pinjaman pelajaran. Norma baru dalam aspek pembelajaran menuntut pelajar untuk menyesuaikan diri kepada pembelajaran secara dalam talian .Terdapat beberapa kajian awal yang telah dijalankan untuk melihat kesediaan dan cabaran yang dialami pelajar semasa berdepan dengan sesi pembelajaran dalam talian. Tidak dapat dinafikan golongan pelajar adalah antara golongan yang paling terkesan kerana mereka terpaksa beralih daripada amalan pembelajaran konvensional iaitu secara bersemuka kepada dalam talian bagi memastikan proses pembelajaran sedia ada tidak terganggu terutama semasa negara terpaksa berdepan dengan impak wabak COVID-19 (Chung, Mohamed Noor \& Mathew 2020; Amani Nawi \& Umi Hamidaton 2020).

Selain itu, capaian internet turut memainkan peranan penting dalam menjamin kelancaran pembelajaran dalam talian. Tidak semua pelajar bernasib baik untuk memperoleh ruang pembelajaran yang kondusif serta pakej internet terbaik memandangkan servis internet yang ditawarkan oleh syarikat telekomunikasi di negara ini bergantung kepada kawasan liputan sama ada terletak di bandar dan luar bandar. Justeru, pelajar yang tinggal di kawasan luar bandar yang mempunyai capaian internet terhad terpaksa berulang alik ke bandar untuk menghadiri kuliah, menyiapkan tugasan dan peperiksaan online serta melibatkan diri dalam perbincangan bersama rakan sekuliah bagi memastikan mereka tidak mengalami keciciran dalam pelajaran.

\section{Isu Kesejahteraan Keluarga}

Pandemik COVID-19 adalah merupakan masalah global yang dilihat mampu mengganggu gugat kesejahteraan keluarga. Wabak COVID-19 dilihat sebagai faktor yang menyumbang kepada tekanan dalam institusi keluarga memandangkan dunia baru sahaja mengenal pasti penularan virus pembunuh ini dan masih bergelut dengan pelbagai ketidakpastian berkaitannya (Samantha et al., 2020). Semasa tempoh PKP dilaksanakan, semua institusi pendidikan yang melibatkan semua peringkat termasuklah sekolah rendah, menengah dan institusi pendidikan tinggi telah ditutup. Perkhidmatan taman asuhan kanak-kanak juga tidak terkecuali. Situasi ini telah memberikan tekanan kepada ibu bapa kerana mereka perlu bertanggungjawab dalam aspek pendidikan anak-anak serta dalam masa yang sama terpaksa memastikan aspek pengurusan rumah berjalan lancar (Wang et al., 2020). Tekanan dan emosi negatif ibu bapa turut mengundang kepada gaya asuhan yang kasar (Chung et al., 2020) dan berpotensi untuk berlakunya penderaan kanak-kanak (McPherson et al, 2008). 
Selain itu, Kementerian Pembangunan Wanita, Keluarga dan Masyarakat melaporkan bahawa terdapat sebanyak 1,929 aduan berhubung kes keganasan rumah tangga berlaku di sepanjang tempoh PKP bermula Mac 2020. Keganasan rumah tangga yang paling banyak dilaporkan ialah keganasan yang menyebabkan kecederaan atau mencederakan mangsa secara fizikal yang kemudiannya disusuli dengan keganasan secara sengaja atau cuba meletakkan mangsa dalam keadaan ketakutan terhadap kecederaan fizikal serta pelaku melakukan penderaan psikologi dan emosi terhadap mangsa (Norzamira, 2020).

\section{Penyebaran Berita Palsu dan Kawalan Pergerakan}

Ketika Malaysia sedang berdepan krisis COVID-19 ini dan petugas barisan hadapan bertungkus-lumus mengekang penularan wabak itu, penyebaran berita palsu dan maklumat tidak tepat juga mula berleluasa (Saifuddin, 2020). Apabila isu berita palsu ini tersebar luas, masyarakat mula merasa takut yang melampau dan boleh menjurus kepada perasaan kemurungan. Isu ini akan menjadi lebih buruk sekiranya masyarakat mempercayai bulat-bulat berita yang digembar-gemburkan. Pihak Kementerian Dalam Negeri (KDN) melaporkan sebanyak 266 kertas siasatan telah dibuka dalam tempoh 6 bulan pertama tahun 2020, antaranya melibatkan kesalahan menghasut dan penyebaran berita palsu atau berunsur hasutan.

Satu kajian menganggarkan kira-kira 800 orang di seluruh dunia dilaporkan meninggal dunia akibat berita palsu berkaitan COVID-19 seperti mengambil 'ubat' mengandungi metanol atau bahan peluntur yang dipercayai boleh mencegah dari jangkitan COVID-19 (Berita Harian, 2020). Perkongsian seperti ini pada hakikatnya boleh mempengaruhi pemikiran dan tingkah laku individu serta mendatangkan kesan negatif kepada masyarakat dan negara. Pengalaman masyarakat dalam menghadapi norma baharu wabak COVID-19 ternyata telah menimbulkan keterujaan baharu di media sosial, terutamanya dengan berkongsi dan menyebarkan berita palsu berkaitan Perintah Kawalan Pergerakan (PKP), jumlah kes harian jangkitan COVID-19, Bantuan Prihatin Nasional (BPN), bantuan Jabatan Kebajikan Masyarakat (JKM) dan hal-hal berhubung pandemik COVID-19 . Akses terhadap maklumat yang lebih banyak secara dalam talian (online) menyebabkan berlaku lambakan informasi data dalam media sosial. Bahkan, budaya penularan berita palsu ini telah mencetuskan kesan pemikiran negatif dalam masyarakat sehingga menimbulkan kepanikan, keterujaan, ketakutan dan permainan emosi yang akhirnya membawa kepada isu kesihatan mental (Sinar Harian, 2020).

\section{Solusi Kemurungan melalui Pengamalan Nilai Agama}

Islam memberikan panduan yang berbeza dalam pemerihalan usaha mengatasi masalah kemurungan. Manusia secara fitrahnya dipengaruhi oleh unsur dalaman yang terdiri daripada perasaan, jiwa dan nafsu. Sekiranya unsur-unsur tersebut mengalami gangguan, maka ia seterusnya akan mempengaruhi tingkah laku dan perbuatan seseorang. Ilmuwan dalam bidang agama menegaskan bahawa proses penyembuhan kemurungan dan masalah mental yang lain boleh dilakukan melalui aspek kerohanian. Ia dilihat sebagai alternatif terbaik untuk merawat penyakit-penyakit mental ini dengan menggunakan ayat-ayat Al-Quran, mendirikan solat, bacaan zikir, doa-doa lazim dan khusus, bermunajat dan melakukan amar ma'aruf sebagaimana yang digariskan oleh syariat Islam (Khairunneezam, 2018).

\section{Terapi melalui Pelaksanaan Solat}

Allah SWT telah memberikan peringatan dan panduan bahawa sekiranya seseorang sentiasa mengingati dan membesarkan keEsaan-Nya, maka Allah SWT akan melindungi individu tersebut sepanjang masa. Dalam Surah al-Baqarah ayat 152, Allah SWT berfirman yang bermaksud;

“Maka ingatlah kepada-Ku. Akujuga akan ingat kepadamu”.

Begitu juga dengan firman Allah SWT dalam Surah al-Baqarah, ayat 153 yang bermaksud;

"Wahai orang-orang yang beriman, mohonlah pertolongan (kepada Allah) dengan sabar dan solat". 
Ini adalah isyarat jelas bahawa Allah SWT akan membantu dan melindungi hamba-Nya mengatasi sebarang permasalahan termasuk masalah mental dan kemurungan sekiranya seseorang itu berusaha dan berdoa dengan penuh kesabaran dan tidak sesekali lalai serta leka dalam melaksanakan solat. Individu yang mengerjakan solat akan diberi perlindungan Allah SWT dan diberikan taufiq dan hidayah untuk menuju kebaikan. Perkataan "daimun" bererti khusyuk dan tenang. Hal ini kerana, ketika menunaikan solat seseorang diwajibkan untuk tuma'ninah agar pelakunya diam dan tenang untuk mendapat khusyuk dalam solat (Ibn Kathir, 2011). Rasa khusyuk ini juga membantu individu dalam mencapai keseimbangan diri.

Khusyuk dalam solat juga adalah salah satu ciri orang mukmin yang berjaya. Dua syarat perlu dilaksanakan agar solat dapat berperanan kepada penyucian dan kesihatan jiwa. Pertama, melakukan solat dengan sempurna, rapi perbuatannya, menjaga rukun dan waktunya, tidak lalai, ikhlas dan menepati kaedah berdasarkan Al-Quran dan Sunnah. Kedua, mendirikan solat dengan penuh khusyuk dan penuh penghayatan. Ini kerana solat yang tidak khusyuk seumpama jasad tanpa roh. Ia kosong dan tidak memberikan kesan kepada penyucian jiwa (Anas, 2012). Solat boleh dijadikan sebagai salah satu terapi dalam menangani stres kehidupan (Khairunnas, 2012). Ia boleh diaplikasikan sepanjang tempoh berhadapan dengan wabak COVID-19 ini. Al-Ghazali berpendapat bahawa solat dapat memberikan ketenteraman jiwa, lantaran solat adalah dilengkapi dengan al-himmah (penumpuan), al-tafahum (pemahaman), al-ta'zim (pengagungan), al-haibah (kehebatan), al-raja' (harap) dan al-haya'(malu).

\title{
Amalan Filantropi (Kedermawanan)
}

Ilchman (2006) mentakrifkan filantropi (sifat kedermawanan) kepada rasa kecintaan kepada manusia yang dipamerkan dalam bentuk pemberian derma dan sedekah kepada orang lain. Sementara Kim Klien (2001) mendefinisikan filantropi sebagai konseptualisasi dari praktik pemberian sumbangan sukarela, penyediaan perkhidmatan sukarela dan persatuan sukarela untuk membantu pihak lain yang memerlukannya sebagai ekspresi rasa cinta. Melalui amalan filantropi, individu sentiasa berasa gembira dan tenang kerana dapat memberi bantuan kepada golongan yang memerlukan. Dalam Surah Muhammad, ayat 12, Allah SWT telah berfirman yang bermaksud:

\begin{abstract}
"Sesungguhnya Allah akan memasukkan orang-orang yang beriman serta mengerjakan amal-amal soleh ke dalam syurga yang mengalir dibawahnya beberapa sungai; dan (sebaliknya) orang-orang kafir menikmati kesenangan di dunia serta mereka makan minum sebagai mana binatang-binatang ternak makan minum, sedang nerakalah menjadi tempat tinggal mereka"
\end{abstract}

Antara amal soleh yang disukai oleh Allah SWT adalah seperti yang dijelaskan dalam ayat di atas ialah apabila hamba-Nya berlumba-lumba membelanjakan harta kekayaan untuk kebaikan kepada individu yang memerlukannya.

Tahap kefahaman yang tinggi terhadap amalan filantropi dalam kalangan masyarakat amatlah penting ketika negara dilanda pandemik COVID-19 ini. Hal ini kerana ia dapat memastikan individu yang kurang bernasib baik, dapat dibantu dari aspek ekonomi. Sepanjang tempoh PKP ini, banyak pihak sama ada dari badan kerajaan atau bukan kerajaan yang menyumbang dana bagi membantu individuindividu yang memerlukan. Hal ini dapat dilihat apabila MyCARE Johor berjaya mengumpul dana dari orang ramai sebanyak RM6,300, di mana dengan dana ini MyCARE Johor dapat menyumbangkan barangan keperluan asas kepada golongan sasar di selatan tanah air (Rosyahaida, 2020). Selain itu, terdapat juga individu yang secara sukarela menjahit pakaian pelindungan (Personal Protective Equipment, $P P E$ ) untuk disalurkan kepada seluruh hospital di Malaysia. Badan kerajaan juga seperti PETRONAS melalui Yayasan PETRONAS telah memberi sumbangan peralatan dan bekalan perubatan bernilai RM20 juta bagi membantu hospital dan petugas barisan hadapan penjagaan kesihatan (Mahani Ishak, 2020). 


\section{Terapi Berzikir}

Memperbanyakkan zikir akan lebih mendekatkan diri kepada Allah dan juga mampu membuatkan hati menjadi lebih tenang. Dalam satu hadis, Rasulullah SAW bersabda yang bermaksud;

"Sesiapa yang berselawat kepadaku pada waktu pagi sepuluh kali dan pada waktu petang sepuluh kali, ia akan memperoleh syafaatku pada hari kiamat." (Riwayat Tabrani).

Allah SWT juga berfirman dalam Surah al-Ahzaab, ayat 56 yang bermaksud;

"Sesungguhnya Allah dan malaikat-Nya berselawat (memberi segala penghormatan dan kebaikan) kepada Nabi (Muhammad SAW), wahai orangorang yang beriman berselawatlah kamu kepadanya serta ucapkanlah salam sejahtera dengan penghormatan yang sepenuhnya."

Amalan zikir ini seharusnya menjadi amalan harian atau sekurang-kurang dibaca selepas setiap kali solat fardu. Setiap amalan ini perlu dilaksanakan secara istiqamah (berterusan). Zikir merupakan salah satu terapi psikiatri yang ampuh untuk diterapkan pada jiwa manusia (Rahayu, 2019). Selain dari berselawat ke atas Rasulullah S.A.W, kita juga boleh beramal dengan zikir dan wirid yang telah diamalkan oleh para salafussoleh yang mana ia boleh menjadi perisai buat kita agar dihindari daripada segala penyakit atau perkara-perkara yang tidak baik (Ahmad Sharifuddin, 2020).

\section{Terapi Berdoa}

Doa adalah lafaz puji-pujian untuk memohon sesuatu yang dihajati daripada seorang hamba kepada Allah SWT. Firman Allah SWT dalam Surah Ghafir ayat 60 yang bermaksud;

\section{"Berdoalah kamu kepada-Ku nescaya Aku perkenankan doa permohonan kamu."}

Al-Ghazali menyatakan bahawa doa adalah salah satu mekanisme tazkiyah al-nafs yang dapat memberikan ketenangan kepada jiwa manusia yang gelisah, kerana apabila berdoa, jiwanya akan khusyuk mengingati Allah disamping dapat melatih jiwa bersifat rendah diri serta menginsafi kelemahan diri disisi Allah SWT. Doa yang terkabul itu dapat membawa individu Muslim ke arah kesihatan mental dan diganti dengan kedamaian dan ketenangan (Hairunnas, 2006).

\section{Konsep Redha dengan Ujian}

Walau sebesar manapun masalah atau kesukaran yang menyumbang kepada tekanan perasaan dan kemurungan, individu perlu sedar bahawa ia boleh dihadapi dengan jaya jika individu tersebut redha dengan ujian yang dialami. Firman Allah SWT dalam surah al-Fajr, ayat 27-30 yang bermaksud;

\footnotetext{
"Wahai orang yang mempunyai jiwa yang sentiasa tenang tetap dengan kepercayaan dan bawaan baiknya. Kembalilah kepada Tuhanmu dengan keadaan engkau berpuas hati (dengan segala nikmat yang diberikan) lagi diredhai (di sisi Tuhanmu). Serta masuklah engkau dalam kumpulan hamba-hambaku yang berbahagia. Dan masuklah ke dalam Syurgaku."
}

Jika hati dan pemikiran seseorang sentiasa bersandarkan kepada sifat tawaduk, yakin dan syukur kepada Allah SWT, maka dirinya akan diberikan petunjuk dan hidayah-Nya dalam menangani segala tekanan dan kemurungan tersebut (Khairunneezam, 2018). Wabak COVID-19 yang menjadi pandemik ini merupakan musibah yang harus ditempuhi dengan sabar. Ia merupakan takdir (ketentuan) yang telah ditetapkan oleh Allah SWT. Setiap dari manusia tanpa mengira agama, bangsa, status dan keturunan harus melalui musibah ini. Tidak ada darinya yang terkecuali. Oleh yang demikian, 
sekiranya konsep ini dihayati dan difahami maka, dapat menghindarkan diri dari kesedihan, kekecewaan dan emosi melampau yang menjerumuskan diri kepada kecelaruan dan kemurungan.

\section{Kesimpulan}

Memandangkan negara kini berhadapan gelombang ketiga penularan COVID-19 dengan catatan tinggi kes baharu harian yang mendadak, terdapat individu yang kembali menghadapi tekanan, gangguan emosi serta kemurungan. Graf kerisauan dan kebimbangan dialami rakyat termasuklah golongan pekerja serta majikan bakal kembali meningkat berikutan situasi semasa pandemik.

Tuntasnya sepanjang wabak COVID-19 ini melanda, individu, pekerja, pelajar, mahupun institusi keluarga terpaksa bergelut dengan pelbagai dugaan dan cabaran. Walaupun dalam menghadapi pelbagai tekanan psikologi ekoran kehilangan sumber pendapatan, pekerjaan, urusan kerja tergendala, namun ia bukanlah asbab untuk terus berpeluk tubuh dan membiarkan hari yang berlalu dengan tekanan kerana setiap manusia mampu membuat pilihan dan perubahan.

Asas yang paling kukuh untuk melawan kemurungan dan apa jua masalah kesihatan mental yang lain adalah melalui keimanan yang kuat terhadap tauhid dan ajaran nabi. Oleh itu, perkara-perkara yang bersifat negatif seperti tekanan (stress and burnout), kerja yang tidak terjamin (job insecurity) dan pelbagai lagi aspek negatif berkaitan kehidupan seharian haruslah ditangani dengan bijak agar kesejahteraan kendiri dapat dicapai dan tidak dibelenggu dengan masalah kemurungan.

\section{Penghargaan}

Sekalung penghargaan ditujukan kepada Universiti Sains Islam Malaysia atas pembiayaan geran penyelidikan yang bertajuk "Faktor Yang Mempengaruhi Kesejahteraan Kendiri Terhadap Tekanan Psikologi Semasa Wabak COVID-19” (PPPI/COVID19_0120/FKP/051000/13820).

\section{Rujukan}

Abdul Hamid Muhammad. (1988). Al-Ghazali: Ihya Ulum al-Din (Terjemahan). Singapura: Pustaka Nasional Pte Ltd.

Al-Ghazali. (2000). Ihya Ulumuddin. Thahqiq Abdul Rahim Al Husin Al Iraqi. Kaherah: Dar alTakwa li al-Turath.

Amani Nawi \& Umi Hamidaton Mohd Soffian Lee. (2020). Penerimaan Pelajar Universiti Sains Islam Malaysia (USIM) terhadap Penggunaan Microsoft Teams sebagai Platform Pembelajaran-Satu Tinjauan. 3rd International Seminar on Islamic and Science. 15 October 2020, Nilai: Universiti Sains Islam Malaysia

American Psychological Association. (2011). Capaian pada 2 Feb 2020 dari http://www.apa.org/about/division/div36.aspx.

Berita Harian (2020). COVID-19 cetus krisis kesihatan mental global - PBB. Capaian pada 24 November 2020 dari https://www.bharian.com.my/dunia/eropah/2020/05/688677/COVID-19cetus-krisis-kesihatan-mental-global-pbb

Bowlby J. (1952). Maternal care and mental health. Monograph World Health Organization. Geneva.

Che Zarrina Sa'ari \& Norhafizah Musa. (2019). Pendekatan psikoterapi Islam dalam menguruskan tekanan pesakit kronik. Jurnal Usuluddin, 47(1), 1-34.

Chung, E., Noor, N. M., \& Vloreen Nity Mathew. 2020. Are You Ready? An Assessment of Online Learning Readiness among University Students. International Journal of Academic Research in Progressive Education and Development, 9(1), 301-317.

Creswell, J. W., \& Plano Clark, V. L. (2011). Designing and conducting mixed methods research. (2nd ed.). Thousand Oaks, CA: Sage Publications Ltd. 
Erda Khursyiah Basir. (2020, 0ktober 14).Gelombang ketiga COVID-19: Apa cerita kesihatan mental pekerja, majikan? Bernama. Dicapai pada 10 Oktober 2020 dari https://www.bernama.com/bm/rencana/news.php?id=1889166

Firdaus Abdul Ghani. (2020, Mac 14). Impak psikologi akibat wabak COVID-19. Astro Awani. Dicapai pada 20 Oktober 2020 dari https://www.astroawani.com/berita-malaysia/impakpsikologi-akibat-wabak-covid19-233648

Firdaus Mukhtar \& Tian P. S. O (2011). A Review on Assessment and Treatment for Depression in Malaysia. Hindawi Publishing Corporation Depression Research and Treatment. 9, 1-8.

Garcia-Toro M., Ibarra O., Gili M., Serrano MJ., Olivan B., Vicens E., \& Roca, M. (2012). Four hygienic-dietary recommendations as add-on treatment in depression: A randomized-controlled trial. Journal Affect Disorder, 140(2), 200-203.

Hafidzul Hilmi. (2020, Ogos 5). Bekas juruterbang terjun tingkat 12 selepas hilang kerja. mymetro. Dicapai pada 15 November 2020 dari

https://www.hmetro.com.my/mutakhir/2020/08/607109/bekas-juruterbang-terjun-tingkat-12selepas-hilang-kerja

Hedayat-Diba Z. Psychotherapy with Muslims. In: Richards PS, Bergin AE, editors. Handbook of psychotherapy and religious diversity. Washington, DC: American Psychological Association; 289-314.

Heyman, J., Buchanan, R., Musgrave, B., \& Menz, V. (2006). Social workers attention to clients' spirituality: Use of spiritual interventions in practice. Arete, 30, 78-89.

Hidayatul Akmal Ahmad, (22 Ogos 2018). Syor Malaysia miliki indeks psikologi. Berita Harian. Capaian pada 2 Feb. 2020 dari, https://www.bharian.com.my/berita/nasional/2018/08/464767/syor-malaysia-miliki-indekspsikologi.

Hodge DR. (2005). Social work and the house of Islam: Orienting practitioners to the beliefs and values of Muslims in the United States. Social Work Journal, 50,162-73.

Howell, R.T., Chong, W.T., Howell, C.J., \& Schwabe, K. (2012). Happiness and Life Satisfaction in Malaysia. Science Across Cultures: The History of Non-Western Science, 6, 43-55.

Institute for Public Health (IPH) Report. National Health and Morbidity Survey, NHMS (2015). Ministry of Health Malaysia.

Institute for Public Health (IPH) Report. Adolescent Health Survey (2017). National Health and Morbidity Survey, NHMS 2017. Ministry of Health Malaysia.

Communicable Disease. Ministry of Health Malaysia Kuala Lumpur.

Jenkins R., Baingana F., Ahmad R., McDaid D., \& Atun R. (2011). Mental health and the global agenda: core conceptual issues. Mental Health in Family Medicine journal. 8 (2), 69-82.

Khairunneezam, M. N. (2018, Julai 23). Kemurungan dan panduan Islam dalam menghadapinya. Risalah USIM. Dicapai pada 12 November 2020 dari https://www.usim.edu.my/ms/berita/in-ourwords-ms/kemurungan-dan-panduan-islam-dalam-menghadapinya/

King, L.A., \& Pennebaker, J.W. (1998). What's so great about feeling good? Psychological Inquiry, 9, 53-56.

Laporan Indeks Kesejahteraan Psikologi Malaysia IKPM, (2020). Jabatan Perkhidmatan Awam. Capaian pada 2 Februari 2020 dari https://ikpm.jpa.gov.my/

Le, H. N., Berenbaum, H., \& Raghavan, C. (2002). Culture and Alexithymia: Mean Levels, Correlates, and the Role of Parental Socialization of Emotions. Emotion Journal, 2(4), 341-360.

Lucette, A., Ironson, G., Pargamen, K., \& Krause, N. (2016). Spirituality and Religiousness are Associated with Fewer Depressive Symptoms in Individuals With Medical Conditions. Academy of Psychosomatic Medicine, 57(5), 505-513.

Mahani Ishak (Mei 15, 2020).PETRONAS komited hulur bantuan demi kesejahteraan masyarakat. Berita Harian Online. Dicapai pada 1 Oktober 2020 dari https://www.bharian.com.my/berita/nasional/2020/05/688955/petronas-komited-hulur-bantuandemi-kesejahteraan-masyarakat

Mahmoud, V. (1996).African American Muslim families. In: McGoldrick M, Giordano J, Pearce JK, editors. Ethnicity and family therapy. 2nd ed. New York: Guilford Press.

Marcotte D., Margolin, A., \& Avants, SK. (2003). Addressing the spiritual needs of a drug user living with human immunodeficiency virus: A case study. Journal Alternatives Complement Medicine, 9(1), 169-75. 
DOI: https://doi.org/10.47405/mjssh.v5i12.593

Masroom, Mohd Nasir \& Muhamad, Siti \& Panatik, Siti. (2015). Kebimbangan Dari Perspektif Psikologi Islam dan Cara Mengatasinya Berdasarkan Surah Al-Ma'arij. Sains Humanika, 5, 6167.

Mitchell. S., \& Romans, S. (2003). Spiritual beliefs in bipolar affective disorder: Their relevance for illness management. Journal Affect Disorder,75(3), 247-57.

Mohamed Najib Abdul Ghafar (2015). Methodology in Behavioural Research. Johor: Penerbit UTM Press.

Murdock V. (2004). Religion and spirituality in gerontological social work practice: Results of a national survey.

Nor Ezdianie, O., \& Mohd Tajudin, N. (2019). (The al-ghazali psycho-spiritual counseling theory: An alternative approach in counseling interventions). Global Journal Al-Thaqafah, 9(2), 69-78.

Norhafizah Musa \& Che Zarrina Saa'ri. (2019) Pendekatan Psikoterapi Islam dalam Menguruskan Tekanan Pesakit Kronik. Jurnal Usuluddin, 47(1), 1-34.

Noor Shakirah Mat Akhir. (2008). Al-Ghazali and his Theory of The Soul. Pulau Pinang: Penerbit Universiti Sains Malaysia.

Nurrussakinah Daulay. (2014). Pengantar psikologi dan pandangan al-quran tentang psikologi. Indonesia: Kencana Prenada Media Group.

Norlidah Alias (2010). Pembangunan modul pedagogi berasaskan teknologi dan gaya pembelajaran Felder-Silverman Kurikulum Fizik Sekolah Menengah. Kuala Lumpur. Universiti Malaya Publisher

Norzamira Che Noh (2020). Lelaki turut jadi mangsa keganasan rumah tangga. Berita Harian Online. Dicapai pada 1 Disember 2020 dari, https://www.bharian.com.my/berita/wilayah/2020/11/752165/lelaki-turut-jadi-mangsa-keganasanrumah-tangga

Othman Lebar (2018). Penyelidikan Kualitatif: Pengenalan Kepada Teori dan Metode. Perak: Penerbit UPSI.

Rahim KZ1, Khairulnazrin Nasir, \& Saifullah Mamat. (2019) Dimensi Kebebasan dan Limitasi AlTafakkur dalam Proses Psikoterapi Menurut Al-Sunnah: Perbandingan Terhadap Meditasi Komplimentari Bukan Islam. E-Journal of Islamic Thought and Understanding, 2, 15-37.

Ringkasan Wawasan Kemakmuran Bersama. (2019) E-Book. Kuala Lumpur: Percetakan Nasional Malaysia Berhad. Capaian pada 2 Februari 2020 dari, http://dbook.penerangan.gov.my/dbook/dmdocuments/ringkasan_wawasan_kemakmuran_bersam a/mobile/index.html\#p $=1$

Rosyahaida Abdullah (Mac 28, 2020). MyCare Bantu Keluarga Terjejas COVID-19. Harian Metro. Dicapai pada 10 Oktober 2020 dari, https://www.hmetro.com.my/mutakhir/2020/03/559589/mycare-bantu-keluarga-terjejas-COVID$\underline{19}$.

Sapora Sipon (2009). Keperluan elemen agama dalam disiplin ilmu kaunseling. Isu-isu Kaunseling di Malaysia. Kuala Lumpur: Persatuan Kaunseling Malaysia.

Sharifah Basirah Syed Muhsin (2017) Kepulihan al-Halu' berasaskan maqamat Abu Talib al-Makki. tesis PhD, Akademi Pengajian Islam, Universiti Malaya.

Skinner, R. (2018). Tradition, paradigms and basic concepts in Islamic psychology. Journal of religion and health. 1-8.

Sinar Harian. (2020). COVID-19: Masyarakat Hilang Waras Jika Berita Palsu Berleluasa. Dicapai pada 2 November 2020 dari,

https://www.sinarharian.com.my/article/81099/BERITA/Nasional/COVID-19-Masyarakat-hilang waras-jika-berita-palsu-berleluasa, dicapai pada 17 September 2020

Siroj Sorajjakool et al (2008). Disconnection, Depression, and Spirituality: A Study of the Role of Spirituality and Meaning in the Lives of Individuals with Severe Depression. Pastoral Psychology, 56(5), 521-532

Siti Jamiaah Abdul Jalil (2017) Pengaruh program keagamaan dan sokongan sosial terhadap konsep kendiri, kebimbangan dan kemurungan: Kajian dalam kalangan banduan wanita di Malaysia. tesis $\mathrm{PhD}$, Akademi Pengajian Islam,Universiti Malaya.

Siti Zalikhah Md Nor (2002). Kaunseling Menurut Perspektif Islam. Selangor: Dewan Bahasa dan Pustaka. 
DOI: https://doi.org/10.47405/mjssh.v5i12.593

Toghyani, M., Kajbaf, M.B., \& Ghamarani, A. (2018). What Does Islamic Lifestyle Say about Depression Management?. Zahedan Journal of Research and Medical Science, 20(7), 67766.

Walaa M.Sabry, \& Adarsh Vohra (2013). Role of Islam in the management of Psychiatric disorders. Indian Journal of Psychiatry, 55( 2), 205-214.

Wisdom, J., \& Creswell JW. (2013). Mixed Methods: Integrating Quantitative and Qualitative Data Collection and Analysis While Studying Patient-Centered Medical Home Models. Rockville, MD: Agency for Healthcare Research and Quality. AHRQ Publication No. 13-0028-EF.

Yan, Z.,Gaspar, R., \& Zhu, T. (2019). Emerging technologies, Human behaviour and human behavior and emerging technologies. Wiley Online Library. Capaian pada 3 Februari 2020 dari, https://www.researchgate.net/publication/330810847_Editorial_Emerging_technologies_human_. behavior_and_human_behavior_and_emerging_technologies

Yatimah Sarmani \& Mohd Tajudin Mingal. (2011). Teori Kaunseling Al-Ghazali. Kuala Lumpur: PTS Publication. 